INDONESIA ACCOUNTING JOURNAL

VOLUME 2, NUMBER 1, YEAR 2020

${ }^{1}$ Corresponding author

Jurusan Akuntansi

Fakultas Ekonomi dan Bisnis

Universitas Sam Ratulangi

Jl. Kampus UNSRAT

Manado, Indonesia, 95115

E-mail: jeinitamanein@gmail.com

${ }^{2,3}$ Jurusan Akuntansi

Fakultas Ekonomi dan Bisnis

Universitas Sam Ratulangi

Jl. Kampus UNSRAT

Manado, Indonesia, 95115

Article info:

Received 23 January 2020

Accepted 23 January 2020

Available online 23 January 2020

Keywords: cost of production; full costing; basic cost of order

JEL Classification: M11, M13

DOI: http://doi.org/10.32400/iaj.27557

\section{Penentuan harga pokok produksi dengan menggunakan metode full costing pada pembuatan rumah kayu (Studi kasus pada CV. Rajawali Tunggal Perkasa - Woloan I Utara)。}

\author{
Jeinita Olviana Manein ${ }^{1}$ \\ David Paul Elia Saerang ${ }^{2}$ \\ Treesje Runtu ${ }^{3}$
}

\begin{abstract}
The main cost of production was a direct and indirect amount of expenses and burdens, to produce goods or services under the right conditions and conditions for which they could be used or sold. This research was done on the CV Rajawali Tunggal Perkasa of a lumber company. The purpose of this study is to know how much profit is gained a measure of both income and sacrifice made. The kind of data used is qualitative data and the source data is the primary data. Results from studies indicate that the calculation of the principal production value to a CV Rajawali Tunggal Perkasa with a tally on the cost of production using the method full error indicates the difference of results. Based on the research, the main cost of production is based on the full yield method better at analyzing the cost of production, it is due to the calculation of principal prices of production by the full income method, not including the cost of administration and the cost of the car's rent into overhead, since those costs are a component of the company's profit assessment report.
\end{abstract}

\section{Pendahuluan}

Seiring dengan perkembangan zaman, kebutuhan hidup manusia makin hari makin meningkat, karena disebabkan oleh gaya hidup yang konsumtif dan selalu berorientasi pada materi. Untuk mencukupi kebutuhan hidup yang setiap saat selalu meningkat, manusia yang hidup pada era 30 tahun lalu, mulai melakukan berbagai terobosan untuk menciptakan lapangan kerja baru antara lain pada bidang industri manufaktur rumah panggung yang terbuat dari kayu, dimana dulunya dibuat untuk menjadi rumah tinggal milik sendiri dan belum dikomersialisasikan karena pada era 30 tahun lalu bentuknya belum terlalu menarik perhatian, sebab pembuatannya masih dikerjakan secara kasar, belum terlalu halus, dan bentuknya masih sederhana.

Namun seiring dengan perjalanan waktu, dampak dari kemajuan ilmu pengetahuan dan teknologi (IPTEK) di Indonesia mulai sangat terasa di segala bidang, khususnya di bidang industri manufaktur, manusia terdorong untuk belajar meningkatkan kemampuan serta keterampilan. Disamping itu karena didukung oleh sarana yang memadai seperti mesin pahat, mesin skap, mesin bor kayu, serta sarana lainnya, maka rumah panggung yang dihasilkan pada saat ini memiliki kualitas yang lebih baik, bentuknya bermacam-macam, hasil pekerjaan pembuatannya lebih halus, dan juga karena rumah-rumah panggung pada saat ini sudah di cat maka membuat banyak orang tertarik dan membeli, sehingga lama kelamaan rumah panggung yang terbuat dari kayu dikomersialisasikan, sebab semakin hari wilayah pemasarannya semakin luas keberbagai daerah di Indonesia bahkan juga diluar negeri. Sekarang ini industri manufaktur, perusahaan dagang, maupun perusahaan jasa, sudah sangat banyak, baik dalam skala makro maupun mikro, maka masing-masing perusahaan melakukan pembenahan terutama mengenai kualitas 
produksi, agar terhindar dari permasalahan yang rumit seperti adanya persaingan ketat di bidang perekonomian serta usaha-usaha yang dilakukan untuk mendapatkan laba dan menguasai pangsa pasar. Disisi lain perusahaan harus berusaha untuk meningkatkan kuantitas dan juga kualitas agar dapat bersaing dengan perusahaan yang lain.

Komponen pembentukan laba memerlukan alat bantu manajemen yang mampu menghasilkan informasi-informasi yang relevan guna pengambilan keputusan ekonomi dan keuangan yang tepat yaitu akuntansi. Akuntansi adalah kegiatan menyediakan data kuantitatif terutama bersifat keuangan dari kesatuan usaha ekonomi yang dapat dipergunakan dalam pengambilan keputusan ekonomi. Salah satu keputusan penting yang harus diambil oleh pihak manajemen adalah menyangkut penentuan harga pokok produksi. Harga pokok produksi merupakan jumlah pengeluaran dan beban yang langsung dan tidak langsung, untuk menghasilkan barang atau jasa di dalam kondisi yang tepat, dimana barang tersebut dapat dipergunakan atau dijual. Perusahaan yang menjadi objek penelitian ini adalah CV. Rajawali Tunggal Perkasa yang merupakan usaha yang bergerak di bidang pembuatan rumah. Perusahaan ini memproduksi rumah kayu sebagai persediaan untuk dijual. Perusahaan menggunakan metode perhitungan akuntansi tradisional yaitu dengan menggabungkan seluruh biaya.

\section{Tinjauan pustaka}

Akuntansi manajemen. Akuntansi manajemen adalah proses mengidentifikasikan, pengukuran, penghimpunan, penganalisaan, penyusunan, penafsiran, dan pengkomunikasian informasi keuangan yang digunakan oleh manajemen untuk merencanakan, mengevaluasi dan mengendalikan kegiatan usaha didalam sebuah organisasi, serta memastikan penggunaan dan akuntabilitas sumber daya yang tepat (Samamora, 2013). Sujarweni (2015) mendefinisikan akuntansi manajemen adalah salah satu bidang ilmu akuntansi yang mempelajari bagaimana cara menghasilkan informasi keuangan untuk pihak manajemen yang selanjutnya akan digunakan untuk pengambilan keputusan. Akuntansi manajemen adalah suatu cabang ilmu akuntansi yang menghasilkan informasi untuk manajemen atau pihak intern perusahaan (Krismiaji dan Aryani, 2011). Sedangkan menurut Kamaruddin (2013), akuntansi manajemen adalah penerapan teknik-teknik dan konsep yang tepat dalam pengolahan data ekonomi historikal yang di proyeksi dari suatu satuan usaha untuk membantu manajemen dalam penyusunan rencana untuk tujuan-tujuan ekonomi yang rasional dan dalam pembuatan keputusankeputusan rasional dengan suatu pandangan kearah pencapaian tujuan tersebut.

Biaya. Menurut Mulyadi (2015:8), biaya adalah pengorbanan sumber ekonomis yang diukur dalam satuan uang, yang telah terjadi, sedang terjadi atau yang kemungkinan akan terjadi untuk tujuan tertentu. Menurut Dunia dan Abdullah (2012:22), biaya adalah pengeluaran-pengeluaran atau nilai pengorbanan untuk memperoleh barang atau jasa yang berguna untuk masa yang akan datang, atau mempunyai manfaat melebihi satu periode akuntansi. Biaya adalah jumlah uang yang dinyatakan dari sumber-sumber (ekonomi) yang dikorbankan (terjadi dan akan terjadi) untuk mendapatkan suatu atau mencapai tujuan tertentu (Harnanto, 2017:22). Sedangkan menurut Siregar et al. (2016:23), biaya adalah kos barang atau jasa yang telah memberikan manfaat yang digunakan untuk memperoleh pendapatan.

Penggolongan biaya. Menurut Supriyono (2011), biaya digolongkan sesuai fungsi pokok dari kegiatan/aktivitas perusahaan, penggolongan biaya sesuai dengan periode akuntansi dimana biaya akan dibebankan, penggolongan biaya sesuai dengan tendensi perubahannya terhadap aktivitas atau kegiatan atau volume, penggolongan biaya sesuai dengan objek atau pusat biaya yang dibiayai, penggolongan biaya untuk tujuan pengendalian biaya, dan penggolongan biaya sesuai dengan tujuan pengambilan keputusan. Penggolongan 
biaya adalah proses pengolompokkan biaya secara sistematis atas keseluruhan elemen yang ada ke dalam golongan-golongan tertentu yang lebih ringkas untuk dapat memberikan informasi yang lebih ringkas dan penting (Bustami dan Nurlela 2010 : 12).

Harga pokok produksi. Harga pokok produksi atau product cost merupakan elemen penting untuk menilai keberhasilan (performance) dari perusahaan dagang maupun manufaktur. Penerapan harga pokok produksi merupakan hal yang sangat penting mengingat manfaat informasi harga pokok produksi adalah untuk menentukan harga jual produk serta penentuan harga pokok persediaan produk jadi dan produk dalam proses yang akan disajikan dalam neraca. Pengertian harga pokok produksi menurut Supriyono (2011) adalah suatu pengorbanan atas biaya-biaya produksi yang dapat menghasilkan sebuah produk dalam suatu periode. Menurut Mulyadi (2015:14), harga pokok produksi dalam pembuatan produk terdapat dua kelompok biaya yaitu biaya produksi dan biaya non produksi. Menurut Firdaus (2009:17) pengertian harga pokok produksi (manufacturing cost) adalah biayabiaya yang secara langsung berhubungan dengan produksi yaitu biaya bahan langsung dan tenaga kerja langsung.

Manfaat informasi harga pokok produksi. Menurut Mulyadi (2015:65), penentuan harga pokok produksi memiliki manfaat berikut: menentukan harga jual produk, memantau realisasi biaya produksi, menghitung laba rugi periodik, dan menentukan harga pokok persediaan produk jadi dan produk dalam proses yang disajikan neraca.

Unsur-unsur biaya produksi. Menurut Supriyono (2011) unsur-unsur biaya produksi yaitu: biaya bahan baku, biaya tenaga kerja, biaya overhead pabrik, biaya pemasaran, biaya administrasi dan umum, dan biaya keuangan. Adapun unsur-unsur biaya produksi yaitu biaya bahan langsung adalah semua bahan baku yang membentuk bagian integral dari produk jadi dan dimasukkan secara eksplisit dalam perhitungan biaya produksi (Carter dan
Usry, 2014:40). Tenaga kerja langsung adalah tenaga kerja yang melakukan konversi bahan baku langsung menjadi produk jadi dan dapat dibebankan secara layak ke produk tertentu (Carter dan Usry, 2014:40). Biaya overhead pabrik juga disebut overhead manufaktur, beban manufaktur, atau beban pabrik terdiri atas semua biaya manufaktur yang tidak ditelusuri secara langsung ke output tertentu, overhead pabrik biasanya memasukkan semua biaya manufaktur kecuali bahan baku langsung dan ternaga kerja langsung (Carter dan Usry, 2014:42).

Metode penentuan harga pokok produksi. Menurut Mulyadi (2014:17), pengertian metode full costing adalah metode penentuan harga pokok produksi kedalam harga pokok produksi, yang terdiri dari biaya bahan baku, biaya tenaga kerja langsung, dan biaya overhead pabrik, baik yang berperilaku variabel maupun tetap, dengan demikian harga pokok produksi menurut full costing terdiri dari unsur biaya produksi. Menurut Mulyadi (2014:18), metode variable costing adalah metode penentuan harga pokok produksi yang memperhitungkan biaya produksi yang berperilaku variabel, ke dalam harga pokok produksi, yang terdiri dari biaya bahan baku, biaya tenaga kerja langsung, dan biaya overhead pabrik variabel.

Metode pengumpulan harga pokok produksi. Menurut Mulyadi (2015:35), metode perhitungan biaya berdasarkan pesanan adalah dalam metode ini biaya-biaya produksi dikumpulkan untuk pesanan tertentu dan harga pokok produksi per satuan dihitung dengan cara membagi total biaya produksi untuk pesanan tersebut dalam jumlah satuan produk dalam pesanan yang bersangkutan. Karakter dari metode harga pokok pesanan menurut Mulyadi (2015:38) adalah sebagai berikut: perusahaan memproduksi berbagai macam produk sesuai dengan spesifikasi pemesan dan setiap jenis produk perlu dihitung harga pokok produksinya secara individual, biaya produksi harus golongkan berdasarkan hubungannya dengan produk menjadi dua kelompok berikut ini: biaya produksi langsung dan biaya produksi tidak langsung. Biaya produksi langsung terdiri dari biaya 
bahan baku dan biaya tenaga kerja langsung, sedangkan biaya produksi tidak langsung disebut dengan istilah biaya overhead pabrik, biaya produksi langsung diperhitungkan sebagai harga pokok produksi pesanan tertentu berdasarkan biaya yang sesungguhnya terjadi sedangkan biaya overhead pabrik di perhitungkan ke dalam harga pokok pesanan berdasarkan tarif yang ditentukan dimuka. Harga pokok produksi per unit dihitung pada saat pesanan selesai di produksi dengan cara membagi jumlah biaya produksi yang dikeluarkan untuk pesanan tersebut dengan jumlah unit produksi yang dihasilkan dalam pesanan yang bersangkutan. Metode perhitungan biaya berdasarkan proses menurut Supriyono (2011:217) adalah metode harga pokok proses yang bertujuan untuk menentukan harga pokok atau biaya per unit yaitu dengan membagi biaya pada suatu periode tertentu dengan jumlah unit produk yang dihasilkan pada periode tersebut. Karakteristik dari metode harga pokok proses menurut Bustami dan Nurlela (2010 : 91) adalah sebagai berikut : proses produksi bersifat kontinu, produksi bersifat massa, tujuannya mengisi persediaan yang siap dijual, produk yang dihasilkan dalam suatu departemen atau pusat biaya bersifat homogen, biaya dibebankan ke setiap unit dengan membagi total biaya yang dibebankan ke pusat biaya dengan total unit yang diproduksi, dan akumulasi biaya dilakukan berdasarkan periode tertentu.

\section{Metode penelitian}

Jenis penelitian yang digunakan dalam penelitian ini adalah deskriptif kualitatif. Pendekatan kualitatif dalam penelitian ini adalah merupakan metode dengan cara mendeskripsikan data-data yang sudah ada, dan gambaran maupun uraian yang sudah jelas untuk mengetahui penentuan harga pokok produksi dengan menggunakan metode full costing dalam pembuatan rumah kayu. Penelitian ini dilaksanakan di CV. Rajawali Tunggal Perkasa. Perusahaan ini terletak di Desa Woloan 1 Utara, Kota Tomohon, Sulawesi Utara.
Data merupakan sekumpulan informasi yang diperlukan untuk mengambil keputusan. Data kuantitatif adalah data yang diukur dalam suatu skala numerik (angka) namun dalam statistik semua data kualitatif umumnya dikuantitatifkan agar dapat diproses lebih lanjut (Kuncoro, 2003 :124). Data kualitatif adalah data yang tidak dapat diukur dalam skala numerik (angka) atau data yang disajikan dalam bentuk deskriptif atau berbentuk uraian (Kuncoro, 2003:124). Jenis data yang digunakan dalam penelitian ini adalah data kualitatif yaitu berupa data yang disajikan atau dalam bentuk uraian dan data kuantitatif yaitu berupa tabel perhitungan.

Menurut Kuncoro (2003), sumber data dibedakan atas dua jenis yaitu data primer dan data sekunder. Data primer adalah data yang diperoleh langsung dari sumbernya dengan survey lapangan, diamati dan dicatat oleh peneliti dengan menggunakan semua metode pengumpulan data original. Data sekunder adalah data yang diperoleh dari literatur-literatur yang ada, buku-buku yang berupa dokumentasi dan berasal dari perpustakaan yang digunakan sebagai acuan atau teoritis dalam penelitian ini. Sumber data yang digunakan dalam penelitian ini adalah data primer. Data primer berupa data yang diambil secara langsung dari perusahaan melalui wawancara dengan pimpinan dan karyawan yang terkait dengan objek yang diteliti. Data primer yang diambil berupa biaya bahan baku (langsung, tidak langsung dan penolong), biaya tenaga kerja langsung, biaya overhead pabrik (variabel dan tetap). Penelitian ini menggunakan metode pengumpulan data dalam bentuk wawancara, dan dokumentasi.

Menurut Sugiyono (2014 : 206) analisis deskriptif adalah statistik yang digunakan untuk menganalisis data dengan cara mendeskripsikan atau menggambarkan data yang telah terkumpul sebagaimana adanya tanpa bermaksud membuat kesimpulan yang berlaku untuk umum atau generalisasi. Penelitian ini menggunakan metode analisis deskriptif. Proses analisis dalam penelitian ini berbentuk wawancara, pengambilan data, analisis dan pembahasan, kesimpulan, saran. 


\section{Hasil penelitian dan pembahasan \\ Hasil penelitian}

Hasil penelitian yang dilakukan terhadap penentuan harga pokok produksi dengan menggunakan metode tradisional (CV. Rajawali Tunggal Perkasa), penelitian ini menemukan bahwa seluruh biaya diklasifikasikan dalam biaya produksi yaitu biaya bahan baku, biaya tenaga kerja langsung, biaya overhead pabrik, biaya administrasi, sewa transportasi, sewa tanah, biaya listrik, biaya pulsa telepon genggam, dan biaya pemasaran sehingga total harga pokok produksi perusahaan adalah Rp. 321.418.234. Hal ini menyebabkan penentuan harga pokok produksi jadi lebih tinggi dan berdampak terhadap penentuan harga jual. Tabel 1 menyajikan biaya perhitungan harga pokok produksi menggunakan metode tradisional.

Tabel 1. Perhitungan Harga Pokok Produksi

\begin{tabular}{lr}
\hline Tipe 5x6 (1 Kamar) & \\
Bahan Baku & Rp. 40.640.000 \\
Tenaga Kerja Langsung & Rp. 20.000.000 \\
Overhead Pabrik & Rp. 15.804 .078 \\
Total & Rp. 76.444.078 \\
\cline { 2 - 2 } Tipe 7x9 (2 Kamar) & \\
Bahan Baku & \\
Tenaga Kerja Langsung & Rp. 57.132 .000 \\
Overhead Pabrik & Rp. 30.000 .000 \\
Total & Rp. 15.804 .078 \\
\cline { 2 - 2 } $\begin{array}{l}\text { Tipe 7x14 (3 Kamar) } \\
\text { Bahan Baku }\end{array}$ & Rp. 102.936.078 \\
Tenaga Kerja Langsung & \\
Overhead Pabrik & Rp. 81.234 .000 \\
& Rp. 45.000.000 \\
\cline { 2 - 2 } & Rp. 15.804 .078 \\
\hline
\end{tabular}

Harga Pokok Produksi $\quad$ Rp. 321.418.234

Sumber: CV. Rajawali Tunggal Perkasa, 2019

Tabel 1 menunjukkan bahwa terdapat pemakaian bahan baku, biaya tenaga kerja langsung, dan biaya overhead pabrik pada berbagai tipe $(5 \times 6,7 \times 9,7 \times 14)$. Ketiga tipe ini yang sangat sering diproduksi atau paling banyak diminati. Hasil dari penjumlahan (biaya bahan baku + biaya tenaga kerja langsung + biaya overhead pabrik) per tipe memperoleh harga pokok produksi sebesar Rp. 321.418.234.

\section{Pembahasan}

Tabel 2 menunjukkan bahwa total biaya bahan baku dalam pembuatan rumah kayu masing-masing ukuran pada CV. Rajawali Tunggal Perkasa adalah tipe 5x6 (1 Kamar) sebesar Rp. 40.640.000, tipe 7x9 (2 Kamar) sebesar Rp. 57.132.000, dan tipe 7x14 (3 Kamar) Rp. 81.234.000. Biaya tenaga kerja langsung yaitu tenaga kerja langsung bagian produksi Rp. 20.000.000, Rp. 30.000.000, dan Rp. 45.000.000 terdiri dari 5-10 orang. Untuk biaya tenaga kerja langsung 20\% untuk pesanan dan $80 \%$ untuk produksi, sehingga biaya tenaga kerja langsung untuk produksi adalah :

$20.000 .000 \times 80 \%=16.000 .000$

$30.000 .000 \times 80 \%=24.000 .000$

$45.000 .000 \times 80 \%=36.000 .000$

Tabel 2. Biaya Bahan Baku

\begin{tabular}{cc}
\hline Tipe & $\begin{array}{c}\text { Total Biaya Bahan } \\
\text { Baku (Rp) }\end{array}$ \\
\hline $5 \times$ 6 (1 Kamar) & 40.640 .000 \\
$7 \times$ (2 Kamar) & 57.132 .000 \\
$7 \times 14$ (3 Kamar) & 81.234 .000 \\
\hline
\end{tabular}

Sumber : Data Olahan, 2019

Tabel 3 menunjukkan masing-masing biaya tenaga kerja langsung berdasarkan 3 (tiga) tipe yang diproduksi perusahaan.

Tabel 3. Biaya Tenaga Kerja Langsung

\begin{tabular}{cccc}
\hline Tipe & $\begin{array}{c}\text { Total } \\
\text { Produksi }\end{array}$ & $\%$ & $\begin{array}{c}\text { Biaya } \\
\text { Tenaga } \\
\text { Kerja } \\
\text { Langsung } \\
\text { (Rp) }\end{array}$ \\
\hline $5 \times 6$ (1 Kamar) & 1 & $100 \%$ & 16.000 .000 \\
$7 \times 9$ (2 Kamar) & 1 & $100 \%$ & 24.000 .000 \\
$7 \times 14$ (3 Kamar) & 1 & $100 \%$ & 36.000 .000 \\
\hline
\end{tabular}

Sumber : Data Olahan, 2019

Berdasarkan pada Tabel 3 total biaya tenaga kerja langsung dalam pembuatan rumah kayu masing-masing ukuran pada CV. Rajawali Tunggal Perkasa adalah tipe 5 x 6 (1 Kamar) sebesar Rp. 16.000.000, tipe 7 x 9 (2 Kamar) sebesar Rp. 24.000.000, dan tipe 7 x 14 (3 Kamar) sebesar Rp. 36.000.000. Biaya overhead perusahaan adalah overhead pabrik tatap dan variabel. 
Biaya overhead tetap yaitu biaya penyusutan mesin dan peralatan, gedung, dan kendaraan Rp. 5.874.078 dan biaya overhead variabel yaitu biaya listrik Rp. 1.100.000, biaya pulsa telepon genggam Rp. 100.000, biaya pemasaran Rp. 2.200.000, dan biaya sewa tanah Rp. 5.000.000. Total biaya overhead perusahaan Rp. 14.274.078. Untuk biaya overhead bagian pesanan $20 \%$ dan produksi dibebankan $80 \%$. Total biaya overhead untuk produksi adalah $14.274 .078 \times 80 \%=$ 11.419.262.

Tabel 4. Biaya Overhead Pabrik

\begin{tabular}{cccc}
\hline Tipe & $\begin{array}{c}\text { Total } \\
\text { Produksi }\end{array}$ & $\%$ & $\begin{array}{c}\text { Biaya } \\
\text { Overhead } \\
\text { Pabrik } \\
\text { (Rp) }\end{array}$ \\
\hline $5 \times 6$ (1 Kamar) & 1 & $100 \%$ & 11.419 .262 \\
$7 \times 9$ (2 Kamar) & 1 & $100 \%$ & 11.419 .262 \\
$7 \times 14$ (3 Kamar) & 1 & $100 \%$ & 11.419 .262 \\
\hline \multicolumn{2}{l}{ Sumber : Data Olahan, 2019} & &
\end{tabular}

Berdasarkan Tabel 4 dapat dijelaskan bahwa dari total biaya overhead pabrik dalam pembuatan rumah kayu pada CV. Rajawali Tunggal Perkasa adalah sebesar Rp. 11.419.262. Tabel 5 menunjukkan perbandingan hasil perhitungan harga pokok produksi dengan menggunakan metode full costing.

Tabel 5. Perbandingan Harga Pokok Produksi dengan menggunakan Metode Full Costing

\begin{tabular}{|c|c|c|c|}
\hline \multirow[b]{2}{*}{ Tipe } & \multicolumn{2}{|c|}{ Harga Pokok Produksi } & \multirow[b]{2}{*}{$\begin{array}{c}\text { Selisih } \\
\text { (Rp) }\end{array}$} \\
\hline & $\begin{array}{c}\text { Perhitungan } \\
\text { Tradisional } \\
\text { (CV. } \\
\text { Rajawali } \\
\text { Tunggal } \\
\text { Perkasa) }\end{array}$ & $\begin{array}{c}\text { Metode } \\
\text { Full } \\
\text { Costing }\end{array}$ & \\
\hline $\begin{array}{l}\text { Tipe } \\
5 \times 6 \\
\text { Kamar) }\end{array}$ & 76.444 .078 & 68.059 .262 & 8.385 .816 \\
\hline $\begin{array}{l}\text { Tipe } \\
7 x 9 \\
\text { Kamar }\end{array}$ & 102.936.078 & 92.551 .262 & 10.385 .816 \\
\hline $\begin{array}{l}\text { Tipe } \\
7 x 14 \text { (3 } \\
\text { Kamar) }\end{array}$ & 142.038.078 & 128.653 .262 & 13.385 .816 \\
\hline Total & 321.418 .234 & 289.263.786 & 32.155 .448 \\
\hline
\end{tabular}

Berdasarkan pada Tabel 5 dapat diketahui bahwa kedua metode perhitungan harga pokok produksi antara metode tradisional dan metode full costing terdapat perbedaan nilai dengan total selisih Rp 32.155.448. Perbedaan nilai yang dihasilkan disebabkan oleh metode perhitungan harga pokok produksi perusahaan yang memasukkan biaya administrasi serta sewa transportasi, sewa tanah, biaya listrik, biaya pulsa telepon genggam, dan biaya pemasaran ke dalam komponen biaya overhead pabrik sehingga perhitungan harga pokok produksi metode tradisional lebih tinggi dari perhitungan harga pokok produksi metode full costing. Pada perhitungan harga pokok produksi metode full costing biaya administrasi dan biaya sewa transportasi tidak dimasukkan sebagai biaya overhead pabrik, karena merupakan biaya yang dibebankan pada laporan rugi laba. Sehingga perusahaan lebih bagus menggunakan metode full costing berdasarkan konsep.

\section{Kesimpulan dan saran \\ Kesimpulan}

Berdasarkan perhitungan dan analisis maka penelitian ini menyimpulkan bahwa penetapan harga jual yang di tetapkan oleh CV. Rajawali Tunggal Perkasa masih menggunakan metode harga jual yang ditetapkan oleh produsen, yaitu harga jual = biaya produksi yang dikorbankan $+20 \%$ dan mengikuti harga pasaran yang telah ditetapkan oleh usaha-usaha sejenis. Dalam penentuan harga pokok produksi perusahaan memasukkan semua unsur biaya ke dalam biaya produksi yaitu biaya bahan baku, biaya tenaga kerja langsung, biaya overhead pabrik, dan biaya administrasi dan umum seperti biaya perlengkapan kantor dan biaya sewa kendaraan (truk) sehingga total harga pokok produksi perusahaan adalah Rp. 321.418.234.

Berdasarkan perhitungan harga pokok produksi dengan metode full costing diperoleh harga pokok produksi lebih rendah yaitu Rp. 289.263.786 dan terdapat selisih Rp.32.155.448. Perhitungan yang digunakan oleh perusahaan memiliki hasil yang berbeda dengan perhitungan berdasarkan metode full costing, dimana pengeluaran untuk biaya produksi berdasarkan metode full costing jauh 
lebih murah dibandingkan dengan perhitungan yang dibuat oleh perusahaan.

Saran

Penelitian ini menyarankan agar CV. Rajawali Tunggal Perkasa menerapkan metode full costing dalam menentukan harga pokok produksi secara konsep karena metode ini menghitung semua komponen biaya dari biaya bahan baku, biaya tenaga kerja langsung dan biaya overhead pabrik baik yang bersifat tetap maupun variabel secara realistis sehingga akan menghasilkan perhitungan yang lebih tepat dan akurat dibandingkan dengan metode yang digunakan oleh perusahaan selama ini. Dengan diterapkan perhitungan ini diharapkan dapat memberikan dampak yang positif bagi CV. Rajawali Tunggal Perkasa terutama dalam menentukan harga jual. Karena dengan adanya perhitungan tersebut pemilik dapat menentukan harga jual dengan laba yang diinginkan.

\section{Daftar pustaka}

Bustami, B., \& Nurlela. (2010). Akuntansi Biaya. Edisi Kedua. Jakarta: Mitra Wacana Media

Carter, W. K., \& Usry, M. F. (2014). Akuntansi Biaya. Diterjemahkan oleh Krista. Buku 1. Edisi 14. Jakarta: Salemba Empat

Dunia, F. A., \& Abdullah, W. (2012). Akuntansi Biaya. Jakarta: Salemba Empat

Firdaus, A. (2009). Akuntansi Biaya. Edisi 2. Jakarta: Salemba Empat

Krismiaji, \& Aryani Y., A. (2011). Akuntansi Manajemen. Yogyakarta: Unit Penerbit Dan Pencetakan Sekolah Tinggi Ilmu manajemen YKPN.

Harnanto. (2017). Akuntansi Biaya : Sistem Biaya Historis. Yogyakarta: BPFE

Kamaruddin, A. (2013). Akuntansi manajemen. Edisi Revisi, Cetakan Ke Delapan. Jakarta: Raja Grafindo Persada.

Kuncoro, M. (2003). Metode Riset untuk Bisnis dan Ekonomi : Bagaimana Meneliti dan Menulis Tesis?. Jakarta: Erlangga.

Mulyadi. (2014). Sistem Akuntansi. Cetakan Keempat. Yogyakarta: Sekolah Tinggi Ilmu Manajemen YKPN

Mulyadi. (2015). Akuntansi Biaya, Edisi 5. Yogyakarta: Sekolah Tinggi Ilmu Manajemen YKPN

Samamora, H. (2013). Akuntansi Manajemen. Edisi III. Jakarta: Stard Date Publisher.

Siregar, B., Suripto, B., Hapsoro, D., Widodo Lo, E., Herowati, E., Kusumasari, L., \& Nurofik. (2016). Akuntansi Biaya. Jakarta: Salemba Empat

Sugiyono. (2014). Metode Penelitian Pendidikan Pendekatan Kuantitatif, Kualitatif, dan R\&D. Bandung: Alfabeta.
Sujarweni, V. W. (2015). Akuntansi Biaya : Teori Dan Penerapannya. Yogyakarta: Pustaka Baru Press.

Supriyono. (2011). Akuntansi Biaya : Pengumpulan Biaya dan Penentuan Harga Pokok. Edisi kedua. Cetakan Kelima belas. Yogyakarta: BPFE. 